Article

\title{
"Argento Deaurato" or "Argento Biancheggiato"? A Rare and Interesting Case of Silver Background in Italian Painting of the XIII Century
}

\author{
Iacopo Osticioli ${ }^{1, *(\mathbb{D})}$, Daniele Ciofini ${ }^{1, *} \mathbb{C}$, Martina Banchelli ${ }^{1} \mathbb{C}$, Laura Capozzoli ${ }^{2}$, \\ Loredana Gallo $^{3}$, Alessandro Lavacchi ${ }^{2}\left(\mathbb{D}\right.$, Barbara Salvadori ${ }^{4}\left(\mathbb{D}\right.$, Paolo Matteini ${ }^{1}(\mathbb{D})$ and \\ Salvatore Siano ${ }^{1}$ \\ 1 Institute of Applied Physics “Nello Carrara” (IFAC) - National Research Council (CNR), \\ 50019 Sesto Fiorentino, Florence, Italy \\ 2 Institute of Chemistry of Organometallic Compounds (ICCOM) - National Research Council (CNR), \\ 50019 Sesto Fiorentino, Florence, Italy \\ 3 Gallo Restauro, University of Florence, 50121 Florence, Italy \\ 4 Institute of Heritage Science (ISPC) - National Research Council (CNR), 50019 Sesto Fiorentino, Florence, Italy \\ * Correspondence: i.osticioli@ifac.cnr.it (I.O.); d.ciofini@ifac.cnr.it (D.C.)
}

Received: 3 March 2020; Accepted: 27 March 2020; Published: 1 April 2020

check for updates

\begin{abstract}
The painting depicting the "Virgin with the Child and two angels" by a Tuscan anonymous artist of the XIII century, has raised great interest regarding the execution technique including the use of silver, applied on wood as a background. An in-depth investigation was carried out especially concerning the burnishing process of the silver leaves as well as a detailed inspection of the nature of the organic compounds over the metal leaf and the degradation products of the silver layer. To this aim, a multianalytical approach was used including UV-VIS microscopy along with an Ultra-High-Resolution Scanning Electron Microscopy (UHR-SEM), as well as Fourier Transform Infrared (FTIR), fluorescence and micro-Raman spectroscopies. As a result, the presence of an oil-resin varnish layer in the uppermost layer and a wax-protein layer between the varnish and the metal layer as well as the evidence that the silver leaf was applied with high accuracy directly to the preparation layer, were clearly demonstrated. Furthermore, degradation products of the silver leaf were identified as sulphides, chlorides, and oxides. The holistic approach herein adopted enabled a step forward in the knowledge of the $13^{\text {th }}$ century silver leaf gilding technique, adding value to the originality of this artwork. In this respect, the scientific evidence led to the assumption that likely this painting originally showed a silver-colored background ("argento biancheggiato") as compared to the initial theory of a case of "argento deaurato".
\end{abstract}

Keywords: multianalytical; SEM-EDS; FTIR; Raman spectroscopy; UV-induced VIS fluorescence; optical microscopy; meccatura; cross-section; mapping; argento dorato

\section{Introduction}

The painting depicting the "Virgin with the Child and two angels" by a Tuscan anonymous artist of the XIII century (Figure 1), has shown elements of great interest regarding the execution technique, such as the presence of a sort of "negative" painting technique trough the wooden support, as well as the use of silver applied on wood as a background. Both these peculiarities legitimized a more in-depth examination of this painting.

The wood-digging technique, often recurring in the Byzantine icons, was actually very rare in Tuscany. The frame of this painting is, in fact, obtained from the panel through a complex and long carpentry work, made even more difficult by the choice of the conifer as wood fiber: the $3 \mathrm{~cm}$ thickness 
of the board has been reduced to obtain the pictorial plane. The frame consists of a $3 \mathrm{~cm}$ flat and wide outer frame. Many examples of "negative painting technique" were found in the area near Pisa from 1100 to the end of 1200. However, rare paintings and dossals were found also in Florence until the early 1300s due to the works of Pacino di Buonaguida (St. Nicholas, St. John The Evangelist, St. Proculus) and Giotto (Polyptych of Badia) as well as in Siena with the works of the Master of Tressa (the Redeemer's dossal and the Madonna "with big eyes"). Originally the back of this painting was protected by a thick "ammanitura" (a layer of gypsum and glue cast on the wooden surface as a substrate for gilding) [1]. Unfortunately, over the centuries, this layer got ruined due to adverse environmental factors (high humidity firstly) and now it is almost gone. The painting was made by using the egg-tempera technique and, later, was veiled with oil mixed with bright lacquers. The palette is composed of a few pigments dominated by red and blue.

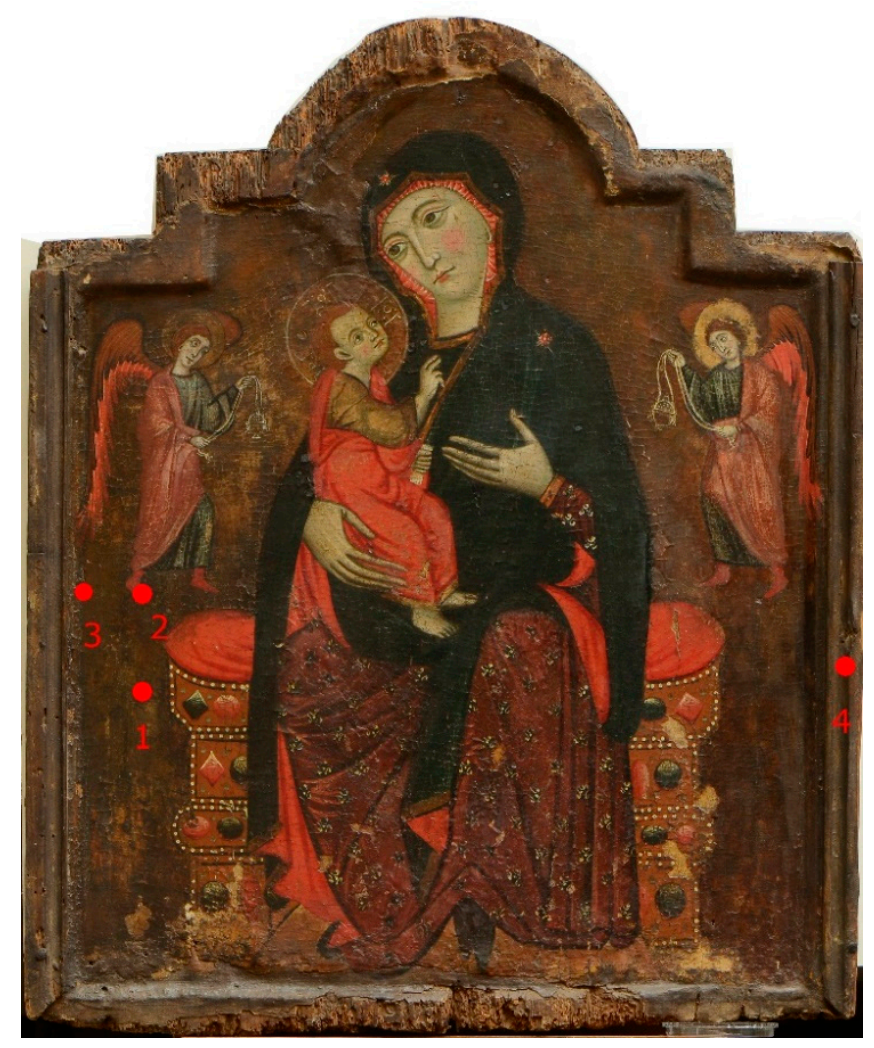

Figure 1. Painting depicting the "Virgin with the Child and two angels" by a Tuscan anonymous artist. Dimensions of the painting: $84 \mathrm{~cm} \times 68 \mathrm{~cm}$. Red spots indicate the areas where sampling was carried out.

Silver leaf was applied in the past, either as "argento deaurato" (glazed silver) as Cimabue (1240-1302) referred for the first time [2,3], or as "argento biancheggiato" (white silver) as Neri di Bicci referred in his "Le Ricordanze"[4], or as "oro di metà" (part-gold). The first, also known as silver "dorato" or "meccato" was glazed on the surface with terpenic resins, often Sandracca, added with dyes such as Arzica, Turmeric, Campeggio (Haematoxylum Campechianum), Saffron, Dragon's Blood, Gommagutta, Aloe, and a plasticizer as formerly beeswax and most recently replaced by Carnauba [5]. In this way, silver leaf was conferred the appearance of the most precious gold leaf. Conversely, silver could be treated with a transparent film in order to protect the foil from degradation as well as to highlight the typical shining-whitish hue of silver (argento biancheggiato). Unfortunately, only little information is available regarding this technique leaving many issues open. The "oro di metà" known in Germany as "Zwishgold" consisted of the use of a silver leaf underneath a thinner gold 
silver [6-8]. The adhesion of the two metal leaves occurred mechanically or alternatively through the use of protein-based adhesives.

The use of silver in medieval Europe is often present in the background of paintings and crosses, as well as the more expensive gold leaves, which, however, until the first half of 1200 , were constituted of low-quality gold called the "pagliola" (20 or $21 \frac{1}{2}$-carat gold). In 1252 in Florence and Genoa and in 1284 in Venice, the minting of 23-carat gold coins led to significant changes to the economic as well as to the artistic world [9]. From this date on, the gold leaves obtained from the coins guaranteed the quality of the precious metal, because it was controlled by the Mint and regulated by rigid rules by the corporations. These leaves were applied by artists over the centuries by using increasingly refined technics such as the use of an orange-colored preparation substrate (the Armenian bole) allowing deep burnishing of the gilded background [10]. The circulation of precious metals was therefore closely linked to economic, political, and social factors [11]: from the 8th to the 13th century, the amount of gold in circulation was drastically reduced in favor of silver. At the end of the 8th century, the monometallic silver was mainly used because it best suited the economic needs of the market of that period. The renewal of the money system began between the 11th and 12th centuries when a silver coin called the "Grosso" was minted for the first time in Venice and soon spread throughout Italy and Europe [12]. This coin was highly sought after so much so that the value of gold with respect to silver was lowered. Thus, it emerges the close interrelationship between the use of certain metals in paintings and in the goldsmith and silversmith. This also explains in that period the widespread use of silver plates in monumental works as for instance, in the "Madonna di Casale" by the Master of Greve at the Uffizi Museum in Florence as well as in the painted cross by Berlinghiero Volterrano at the Museum of St. Mattew in Pisa.

According to information available to us regarding the thirteenth-century technique, the silver as a background was applied in the form of metallic leaves made of irregular squares of $8 \mathrm{~cm}$. The leaves were glued directly on the preparation substrate, smoothed with great accuracy and treated with glue to promote the adhesion of silver leaves. Despite the lack of the bole, some scholars maintain that the metal leaves could be burnished anyway. The subsequent application of a very thick layer of yellowish oil-resin-based compounds appeared to be necessary to make the surface bright as gold.

In this respect, this work aims at providing more clarity on some open issues regarding the execution technique as well as the composition and conservation of the materials used by the artist. For example, more precise information should be provided regarding the burnishing process of the silver leaves, the identification of the organic compounds cast over the silver layer as well as their role, and, the identification of the degradation products of silver. For this reason, a multianalytical approach was mandatory including imaging, spectroscopy, and microscopy techniques, which were applied on cross-sections of some samples taken from the painting where the silver background was present. In particular, UV-Induced VIS Fluorescence (UVIVF) microspectroscopy and imaging along with an Ultra-High-Resolution Scanning Electron Microscopy (UHR-SEM) were employed to study the stratigraphy of the samples in order to gather information on the execution technique and in particular on the burnishing process of the silver leaves. Besides, Fourier Transform Infrared (FTIR) and fluorescence spectroscopies were employed in order to identify the organic materials used as a gold-coloring agent, brightener and protective of the silver background, as well as the binder, used to make the silver leaves to adhere to the preparation layer. Finally, micro-Raman spectroscopy was used to study the degradation mechanism of the silver layer and characterize its corrosion products.

\section{Materials and Methods}

Four samples were taken from the painting in those areas where silver was applied as background in order to study the stratigraphy and gather information on the technical execution and the chemical composition of the artistic materials. Figure 1 shows a view of the entire painting along with the sampling points. Sampling was carried out on original layers avoiding areas affected by most recent interventions of restoration. 
The fragments were cast in polyester resin (Mecaprex 2S from Presi, Grenoble, France), dried and finely polished for cross-sections preparation. The stratigraphies were then observed with a UV-VIS Nikon Eclipse E400 epi-fluorescence microscope (Tokyo, Japan) provided with 5×, 10×, 20×, and 100× objectives and with a Nikon D80 DSLR digital CCD camera. Fluorescence was excited with a mercury lamp and was observed using a V2A Nikon filter cube (Exc.:380-420 nm, DM:420 nm, Bar.:450 nm).

Scanning Electron Microscopy-Energy Dispersive X-Ray Spectrometry (SEM-EDS) measurements were carried out by using a UHR-SEM Gaia 3 FIB/SEM by Tescan (Brno, Czech Republic) placed at the Center of Electronic Microscopies "Laura Bonzi" (Ce.M.E-CNR).

UV-Induced VIS Fluorescence (UVIVF) microspectroscopy was performed with a high-sensitivity Avaspec (Avantes, Apeldoorn, The Netherlands) CCD spectrophotometer (200-1100 nm, grating 300 lines $/ \mathrm{mm}$ ) coupled through an optical fiber to a Nikon Eclipse 400 epi-fluorescence microscope. An HBO mercury short-arc lamp (emission above $295 \mathrm{~nm}$ ) was used as an excitation source, whereas a CFI PlanFluor 100×/1.3 OIL objective lens and the V2A Nikon filter cube to collect fluorescence emission from the varnish layers of the prepared cross-sections.

Fourier Transformed-Infrared (FT-IR) spectra of paint samples in embedded and non-embedded conditions were collected using Diffuse Reflectance Infrared Fourier Transform (DRIFT) and Microattenuated Total Reflection Fourier Transformed-Infrared ( $\mu$-ATR FT-IR) techniques. An Agilent Cary 630 FTIR portable spectrometer (Agilent Technologies, Santa Clara, CA, USA) fitted with a diffuse reflectance accessory for non-contact measures was exploited for Diffuse Reflectance Infrared Fourier Transform (DRIFT) measurements. Pseudoabsorbance spectra $(\log (1 / R) ; R=$ reflectance) were acquired in the $4000-650 \mathrm{~cm}^{-1}$ range, at $8 \mathrm{~cm}^{-1}$ resolution and by averaging 64 scans per sample accumulated. The beam spot size was estimated to be approximately $1 \mathrm{~mm}$. No correction algorithms were applied to DRIFT spectra.

Microattenuated Total Reflection Fourier Transformed-Infrared ( $\mu$-ATR FT-IR) spectra were instead collected using an Agilent Cary 660 FT-IR spectrometer coupled with the Cary 620 Microscope and equipped with a MCT detector. The spectra were acquired in ATR mode with Germanium crystal, collecting 64 scans, with a resolution of $4 \mathrm{~cm}^{-1}$ in the $4000-400 \mathrm{~cm}^{-1}$ range. Spectra were processed using Agilent Resolutions Pro software (Agilent Technologies, Santa Clara, CA, USA ).

Raman measurements were performed under an XPlora Horiba micro-Raman instrumentation (Chelmsford, Essex, UK) using a $785 \mathrm{~nm}$ laser wavelength, a 100× objective, and a diffraction grating of $1200 \mathrm{~g} / \mathrm{mm}$. Raman spectra were collected using an integration time of $10 \mathrm{~s}$ at $4 \mathrm{~mW}$ laser power and were averaged over $N=15$ mapping points.

\section{Results}

The cross-sections analyzed under the UV-light of the microscope show the presence of four distinct layers as indicated in Figure 2d: (1) an uppermost white-opalescent layer, $40 \mu \mathrm{m}$ thick approximately; (2) a thinner (circa $15 \mu \mathrm{m}$ ) fluorescent orangish layer; (3) a very thin (submicron) black layer, likely ascribable to the silver leave; and (4) a very thick whitish preparation layer showing (Figure 2a,b) a double row of holes left by the canvas, which was applied throughout the panel and on the frame by means of a mixture of chalk and glue in order to cushion the movements of the wood. This procedure is in line with the preparatory technique of that time justifying also the considerable thickness of the ground. Analysis carried out on the canvas led to rough linen with a coarse "plain weave" texture (weft/warp ratio 1: 1). 

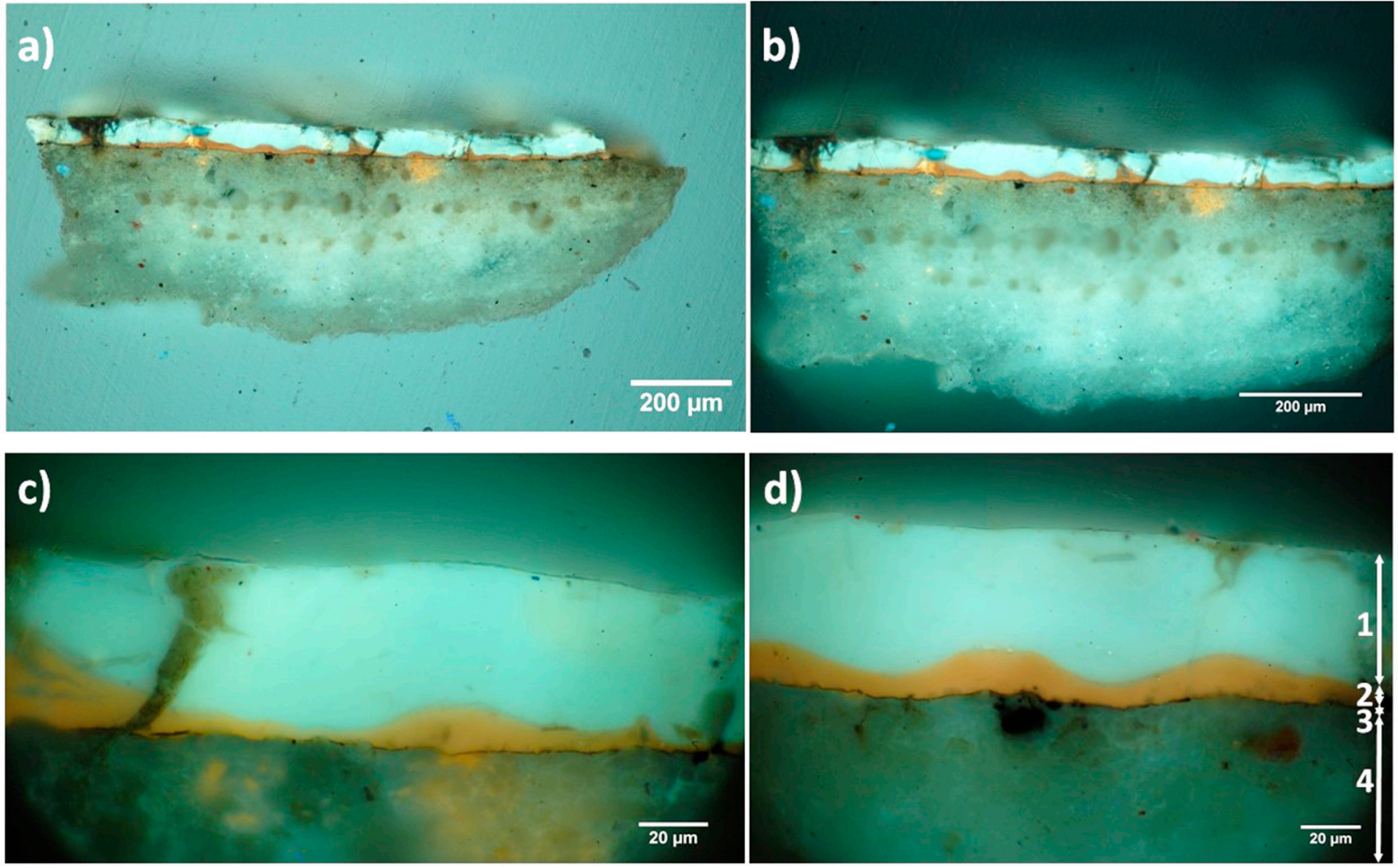

Figure 2. UV fluorescence microscope images of a painting cross-section at different magnification objectives: (a) 10×, (b) 20×, and (c,d) 100×. Four different layers were observed: (1) a white-opalescent layer (circa $40 \mu \mathrm{m}$ ); (2) an orangish layer ( circa $15 \mu \mathrm{m}$ ); (3) a sub-micron black layer; and (4) a very thick whitish preparation layer.

Layers (1) and (2) were distinctly observed only with the UV-light. The same layers observed under VIS-light Optical Microscopy (OM) appeared as a unique layer of yellow color (see Figure 3a). This suggests that its function was likely just to make silver brighter and probably like gold, as clearly displayed in Figure 3b. Noteworthy is the "wavy" form of the orangish layer (layer 2), which is likely ascribable to the grooves left by bristles of brush used to apply layer 1 (see Figure 2c,d).

a)
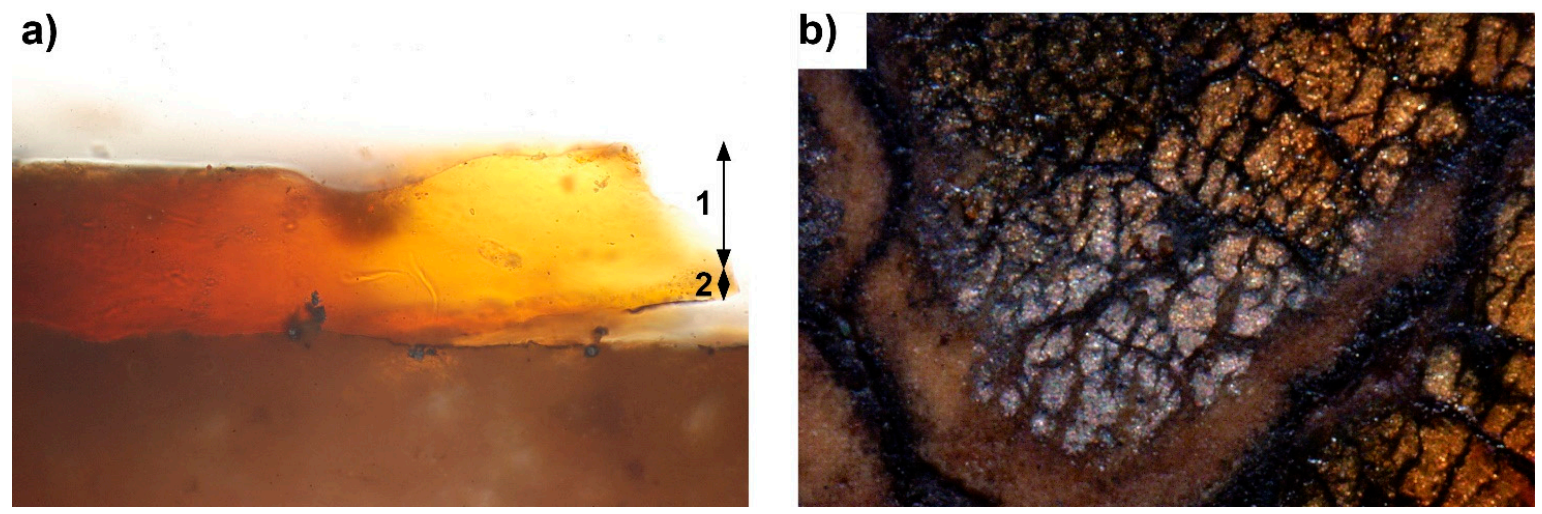

Figure 3. VIS-light image of a painting sample as seen under Optical Microscopy (OM): (a) cross-section of the gilded surface; (b) surface with the varnished (yellow) and unvarnished (gray) silver (Ag) layer.

A better knowledge of the chemical composition of the different layers might provide crucial information to shed light on these issues. The analysis of cross-sections by UVIVF micro-spectroscopy revealed to be very supportive for the discrimination of the two kinds of varnish layers found on top of the silvered surface. Normalized UVIVF spectra collected on the organic layers over the silver leaf are shown in Figure 4. 


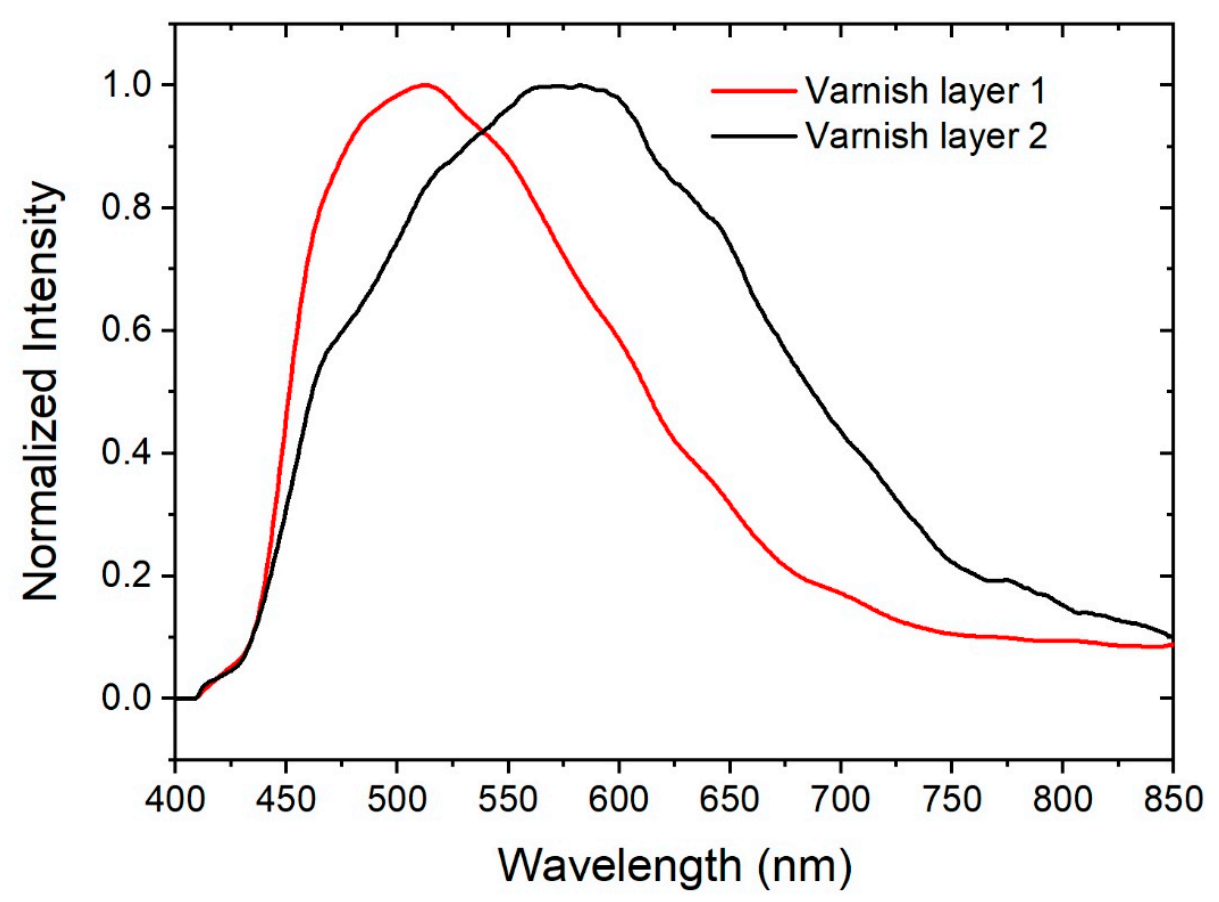

Figure 4. Normalized UV-Induced VIS Fluorescence (UVIVF) spectra showing the different fluorescence emission of the organic layers applied on top of the silver leaf.

Fluorescence maxima $\left(\lambda_{\max }\right)$ were found at about $500(136 \mathrm{~nm}$, measured at Full Width Half Maximum (FWHM) of the band) and $580 \mathrm{~nm}(230 \mathrm{~nm}$ FWHM) for the varnish layer 1 and 2, respectively, according to the scheme shown in Figure 2d. Fluorescence intensity was strongly lower for layer 2 applied over the silver leaf in comparison to the thicker varnish on top (i.e., layer 1), thus suggesting that layer 2 was more aged and ancient. As witnessed by the narrower FWHM, varnish layer 1 is instead more representative of a less complex and aged composition [13]. Unlike varnish layer 2, the blue-shifted fluorescence of the uppermost varnish layer 1 could match more plausibly with a yellow oil medium glaze, but it is rather difficult to obtain more detailed information.

From qualitative comparisons of DRIFT and $\mu$-ATR FT-IR spectra additional and valuable information on the artistic technique were pointed out. In detail, DRIFT analysis of paint fragments before being embedded is shown in Figure 5A.

Starting from the top (Figure $5 \mathrm{~A}$, spectrum a), the broad C $=\mathrm{O}$ stretching band in the $1745-1730 \mathrm{~cm}^{-1}$ region with a shoulder at $1778 \mathrm{~cm}^{-1}$ and the $\mathrm{C}$ - $\mathrm{H}$ bending at $1465 \mathrm{~cm}^{-1}$ were indicative of an oil-based glaze. Signals near $2900 \mathrm{~cm}^{-1}$ (C-H stretching band) were scarcely informative, whereas the clear shoulder-peak at $1676 \mathrm{~cm}^{-1}$ ( $\mathrm{C}=\mathrm{O}$ stretching band) could be from amide I in proteins. The evidence of the latter was found also in other fragments extracted from the same sampling point (Figure 5A, spectrum b). As shown, C-H stretching bands $\left(2954,2920\right.$, and $\left.2852 \mathrm{~cm}^{-1}\right)$, a shoulder of $\mathrm{C}=\mathrm{O}$ at $1725 \mathrm{~cm}^{-1}$ and absorptions in the amide I and II range at 1676, 1635, and $1550 \mathrm{~cm}^{-1}$ are consistent with a protein-based binding medium [14]. Noteworthy are the slightly perceivable signals at 3320 and $3113 \mathrm{~cm}^{-1}$ and the one at $1676 \mathrm{~cm}^{-1}$, which could be assigned firmly to guanine but even to proteins [15]. More detailed information of the outermost layer may be retrieved from the $\mu$-ATR FT-IR stratigraphic analysis of the painting cross-section shown in Figure 2 (Figure 5B spectrum a). It is possible to confirm that the topcoat (i.e., layer 1) is likely constituted of oil, as suggested by the intense $\mathrm{C}=\mathrm{O}$ stretching band at $1730 \mathrm{~cm}^{-1}$ and by the $\mathrm{C}-\mathrm{H}$ stretching $\left(2926-2934\right.$ and $\left.2857 \mathrm{~cm}^{-1}\right)$ and bending (1455-1460 $\mathrm{cm}^{-1}$ ) vibrations. Moreover, the very weak out-of-plane $\mathrm{CH}$ bending vibration at $720 \mathrm{~cm}^{-1}$ is diagnostic for the presence of a lipidic component. The weak band at $1377-1382 \mathrm{~cm}^{-1}$ may also suggest the use of a mixture with a natural resin [16]. However, a direct identification is not 
straightforward, as from FTIR spectra of preheated and aged oil-resin varnishes individual signatures of each component are no longer recognizable [17,18].
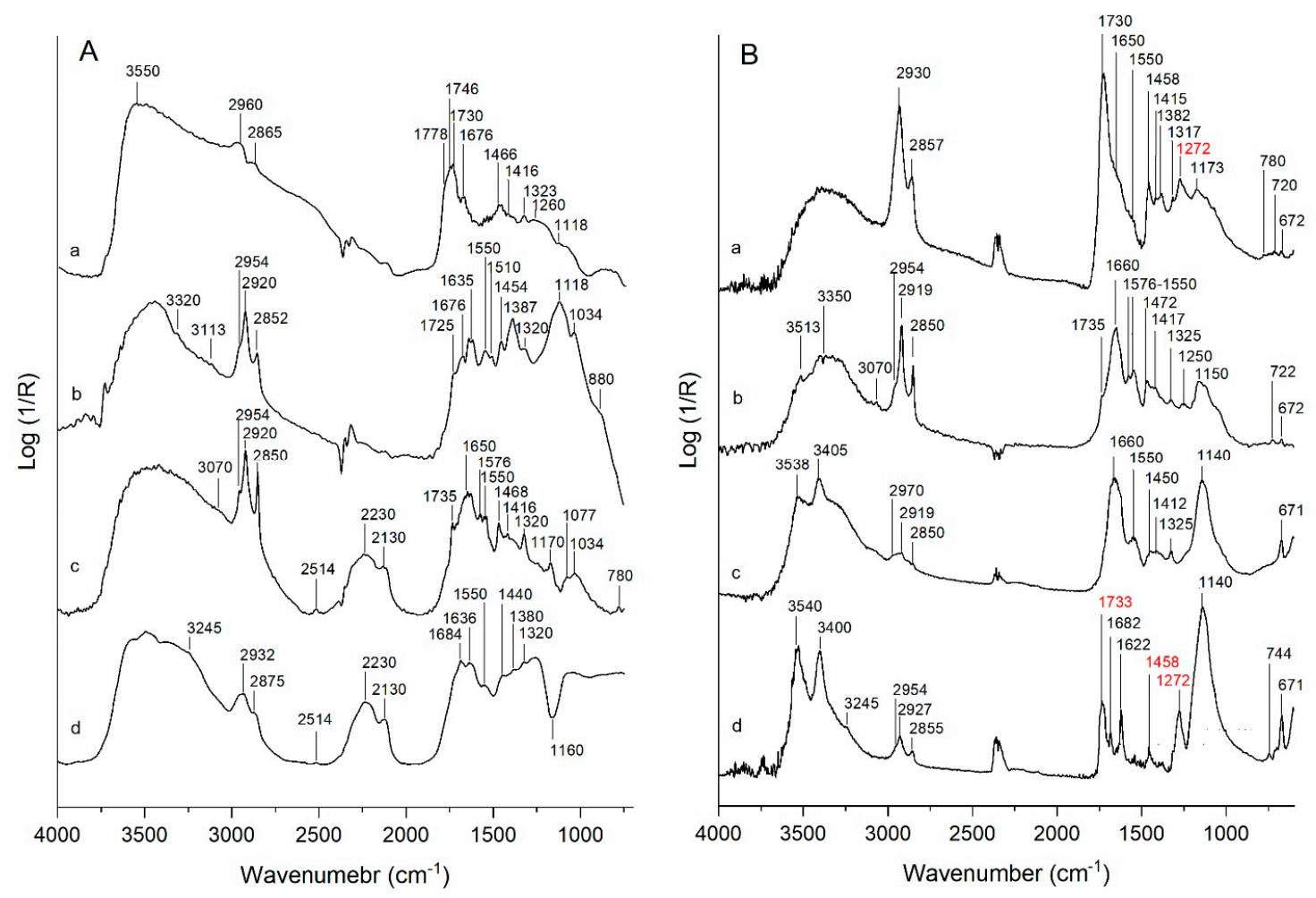

Figure 5. Qualitative comparison of IR spectra of different sampled paint fragments using Diffuse Reflectance Infrared Fourier Transform (DRIFT; A) and Microattenuated Total Reflection Fourier Transformed-Infrared ( $\mu$-ATR FT-IR; B) techniques. DRIFT (A) spectra refer exclusively to different non-embedded samples (a: fragment with varnish on top, $\mathbf{b}$ : fragment with less varnish on top c: degraded silvered surface, d: ground). $\mu$-ATR FT-IR (B) spectra were acquired on embedded (i.e., cross-sections) and non-embedded samples (a: layer 1 of Figure 2, embedded sample, $\mathbf{b}$ : top of the silvered surface, non-embedded sample, c: top of the non-silvered surface, non-embedded sample, $\mathbf{d}$ : ground, embedded sample). Red labels in the plot chart B indicate absorption bands of the polyester embedding resin. A second version of this figure (Figure S1) reporting the vibrational modes assignments of the IR bands in the spectra is shown in supplementary materials.

The broad shoulders at about $1650-1660$ and $1550 \mathrm{~cm}^{-1}$ may be attributed to amide I and amide II, respectively, thus confirming the presence of a proteinaceous substance [19]. In this regard, the $\mu$-ATR FT-IR spectrum collected over the surface of a sampled fragment showing a severely crackled and tarnished silver leaf (Figure 5B, spectrum b) resulting consistently with that of an aged egg yolk, as suggested by the appearance of very weak signal at 3070, the shoulder of C-H stretches at $2954 \mathrm{~cm}^{-1}$, the $C=O$ stretching vibration at $1735 \mathrm{~cm}^{-1}$, and signals at $1650,1576-1550$, and $1460 \mathrm{~cm}^{-1}$ of amide I, amide II, and amide III, respectively $[15,20]$. The thin film over the silvered surface was also characterized by DRIFT, which is well-known to generate high-quality IR spectra in reflection-absorption configuration (Figure 5A, spectrum c). Besides the presence of overlapping signals originating from the underlying gypsum layer (1680 and $1632 \mathrm{~cm}^{-1}$ ), a mixture of proteinaceous material (signals at 1650, 1576, and $\left.1550 \mathrm{~cm}^{-1}\right)$ and calcium oxalates $\left(1636,1320\right.$, and $\left.780 \mathrm{~cm}^{-1}\right)$ was identified [21-23]. The band presence at $1320-1325 \mathrm{~cm}^{-1}$ is typical of whewellite $\left(\mathrm{Ca}\left(\mathrm{C}_{2} \mathrm{O}_{4}\right) \mathrm{H}_{2} \mathrm{O}\right)$ [24]. In the spectrum $\mathrm{c}$ of Figure $5 \mathrm{~A}$, additional signals requiring further attention were the $\mathrm{C}-\mathrm{H}$ stretches near 2900 and $1460 \mathrm{~cm}^{-1}$ and the sharp features of signals at $1735 \mathrm{~cm}^{-1}$ (stretching vibrations of $\mathrm{C}-\mathrm{O}-\mathrm{C}$ groups) and $1170 \mathrm{~cm}^{-1}$ (stretching vibrations of $\mathrm{C}-\mathrm{O}-\mathrm{C}$ groups). Most of these features were detected also by $\mu$-ATR FT-IR 
(Figure 5B, spectrum b) and matched very well with the signatures of waxes (e.g., beeswax, Carnauba, shellac wax, etc.) [16].

Concerning with layers underneath the silver leaf, the use of a protein-based glue was clearly confirmed, as shown by the typical spectral profile (Figure 5B, spectrum c). Calcium sulphate dihydrate was detected as well, which is consistent with the presence of gypsum in the ground $(\mathrm{O}-\mathrm{H}$ stretching bands at 3540 and $3401 \mathrm{~cm}^{-1}$, bending vibration of water at $1625 \mathrm{~cm}^{-1}$ and vibration of sulphate at $1117 \mathrm{~cm}^{-1}$ ), particularly evident in the bulk of this layer (Figure 5B, spectrum d). In spectrum d, some weak bands not ascribable to the ground and red-labeled were attributable to the polyester embedding resin $\left(1731,1458,1256\right.$, and $\left.1275 \mathrm{~cm}^{-1}\right)$. Moreover, DRIFT spectra of the ground (Figure $5 \mathrm{~A}$, spectrum d) figured out a strong and broad $v_{1}+v_{3}\left(\mathrm{SO}_{4}{ }^{-2}\right)$ overtone and combination bands in the $2500-1900 \mathrm{~cm}^{-1}$ range, with maxima at 2230 and $2130 \mathrm{~cm}^{-1}$, and a strong inverted reststrahlen band at $1150-1160 \mathrm{~cm}^{-1}$. These features are unequivocally ascribed to calcium sulphate [25]. The bands at 1636 and $1550 \mathrm{~cm}^{-1}$ were also of amide I and II due to the proteinaceous material present in the ground.

SEM-Back-Scattered Electrons(BSE) images of the Ag layer (Figure 6) in the cross-section showed a very thin $(\approx 100 \mathrm{~nm})$ metal leaf following the shape of the ground underneath. At some points, the Ag layer followed precisely the shape of even single gypsum grains (i.e., the area in the cross-section indicated by a white arrow in Figure 6A) demonstrating an amazing accuracy in the execution technique and suggesting burnishing afterward. As observed in the UV microscope images, a classic bole did not appear here to have been applied since the presence of a layer of organic matter between the metal and the ground was not observed (Figure $6 \mathrm{~A} 1, \mathrm{~B})$. The Ag layer appeared rather be attached directly to the preparation layer most probably trough the protein-based glue detected by FTIR spectra (Figure 5B spectrum c).
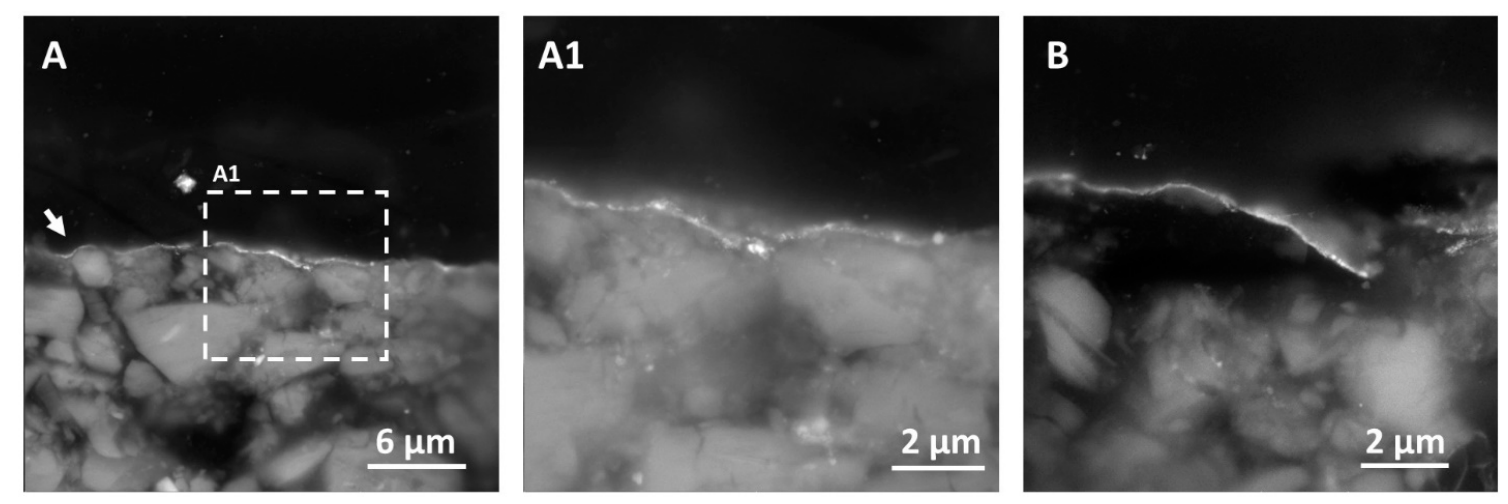

Figure 6. SEM-BSE images of the silver leaf. Figure A and B show the silver leaf in two different areas of the cross-section. Figure A1 shows a magnified view of the area inside the white-dashed square in figure A.

White arrows in Figure 7 indicate scratches in the ground filled with Ag that might suggest the application of more than one single metal leaf overlapped [26].

The elemental composition of the Ag layer was detected performing a SEM-EDS analysis on the surface of a sample not used for resin casting and cross-section preparation. The SEM-EDS spectrum and the area of analysis are shown in Figure 7. In particular, an area devoid of the uppermost varnish layers along with the metal leaf in a relatively good state of conservation (not blacked) was selected for the analysis. Results led to $80 \%$ of $\mathrm{Ag}$ and $2 \%$ of gold ( $\mathrm{Au}$ ) along with other elements such as calcium $(\mathrm{Ca})$, silicon $(\mathrm{Si})$, and aluminum $(\mathrm{Al})$ mainly due to the ground [27]. The presence of chlorine $(\mathrm{Cl})$ and sulphur (S) was ascribable to the degradation products of the silver leaf and Ag sulphide was detected by micro-Raman spectroscopy (see after). The confirmation of the provenance of Au from the Ag layer was achieved mapping the elemental composition of an extended area. In this respect, Figure 8 shows the SEM compositional map of the area A2 (Figure 7) confirming a distribution of gold totally overlapped to that of Ag. Conversely, no presence of gold was detected on the varnish layers ruling 
out the possibility to be a case of varnish loaded with gold. Besides, looking at the $\mathrm{Cl}$ element map in Figure 8 it is possible to observe the degradation of the Ag leaf due to the presence of chlorides, which, however, appeared to be concentrated to some spots.

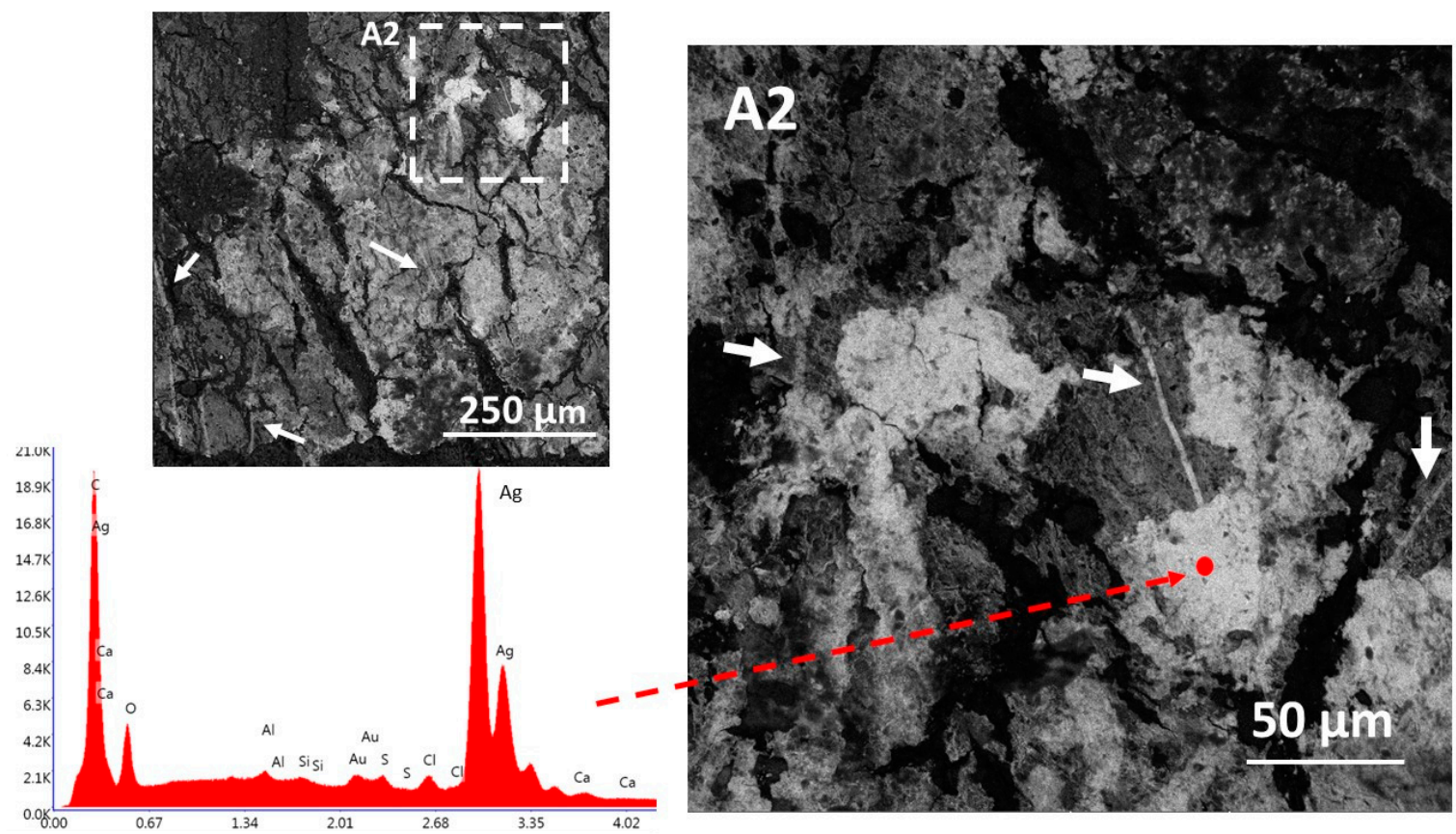

Figure 7. SEM-BSE images of the surface of the untreated painting sample. A SEM-EDS analysis was carried out on the silver leaf.

SEM compositional map (total elements)

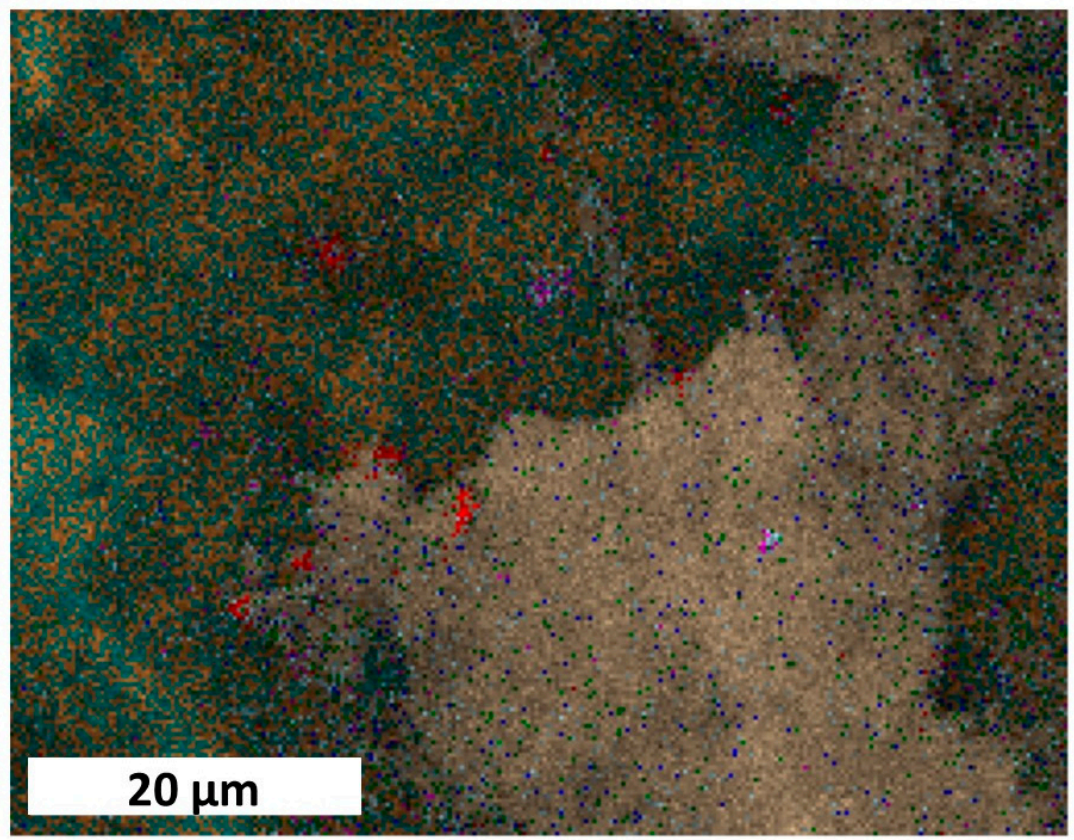

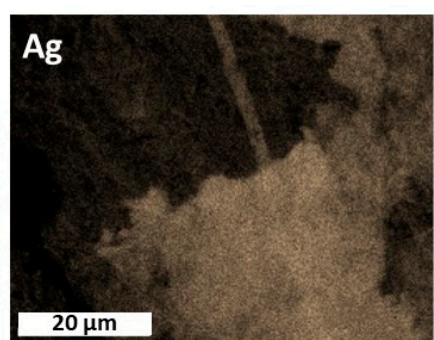
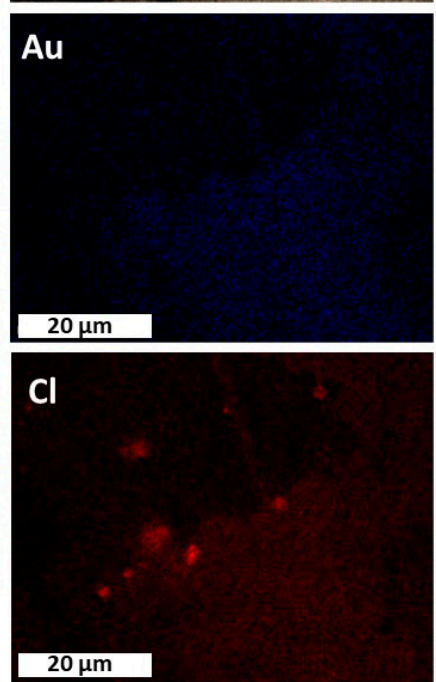

Figure 8. SEM-EDS elemental map of the surface A2 shown in Figure 7. 
The black color of the silver layer suggests a critical conservation state of the metal leaves due to corrosion and oxidation processes. The non-invasive identification and characterization of the degradation products in cross-sections are not trivial because of the very thin layer of silver (submicron) as well as the wide range of compounds that can be found such as chlorides, oxides, sulfides, and sulphates [28]. Micro-Raman spectroscopy carried out with a 100× objective yielding a $2 \mu \mathrm{m}$-sized laser spot on the sample allowed a punctual analysis of the silver layer and enabled the identification of the corrosion and oxidation products of silver. Figure 9 shows typical Raman features of $\mathrm{Ag}_{2} \mathrm{~S}$ at 158,198 , and $281 \mathrm{~cm}^{-1}$ as well as for $\mathrm{Ag}_{2} \mathrm{O}$ at 236, 425, 491, and $563 \mathrm{~cm}^{-1}$ [28,29].

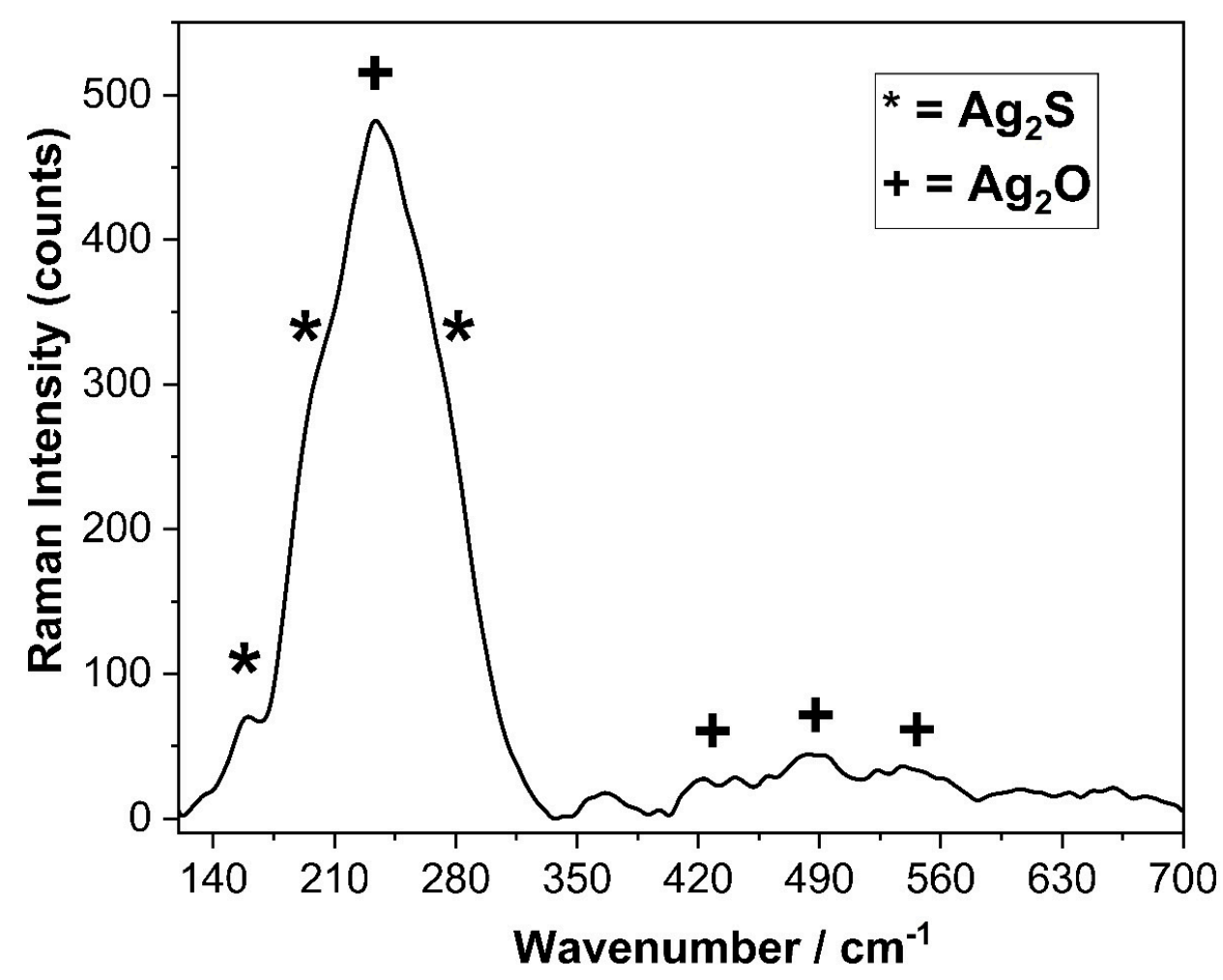

Figure 9. Raman spectrum acquired on the silver layer of the painting cross-section.

Raman spectra carried out on the preparation layer (Figure 10) showed bands of gypsum in the form of calcium sulphate dihydrate $\left(\mathrm{CaSO}_{4} 2 \mathrm{H}_{2} \mathrm{O}\right)$ and anhydrite $\left(\mathrm{CaSO}_{4}\right)$. Raman bands at 415 , 496 , and $675 \mathrm{~cm}^{-1}$ were common to both phases. Bands at 607,627 , and $1015 \mathrm{~cm}^{-1}$ were ascribable to anhydrite whereas the Raman band at $1007 \mathrm{~cm}^{-1}$ was ascribable to calcium sulphate dihydrate. Moreover, micro-Raman analysis carried out on reddish grains in the preparation layer revealed the presence of hematite (Figure 10B).

The coexistence of these two mineral phases of gypsum is due to the lack of temperature control during the cooking of the mineral. Until the second half of the nineteenth century, in fact, the calcination of gypsum did not occur in an efficient way, as there were major difficulties in controlling the temperature of the furnaces [30]. The impossibility of keeping the adequate temperature constant caused uneven cooking of gypsum, which led to a mixture of anhydrite and calcium sulphate dihydrate. In this respect, a Raman analysis mapping performed at different depth $(Z)$ on the ground of the cross-section (Figure 11) confirmed that the distribution of the two mineral phases varied with the distance from the surface $(Z=0)$. Specifically, Raman spectra acquired at different $Z$ distance indicated the prevalence of calcium sulphate dihydrate phase close to the Ag leaf, whereas both dihydrate and anhydrite calcium sulphate contributed to the spectra recorded in the bulk ground. 

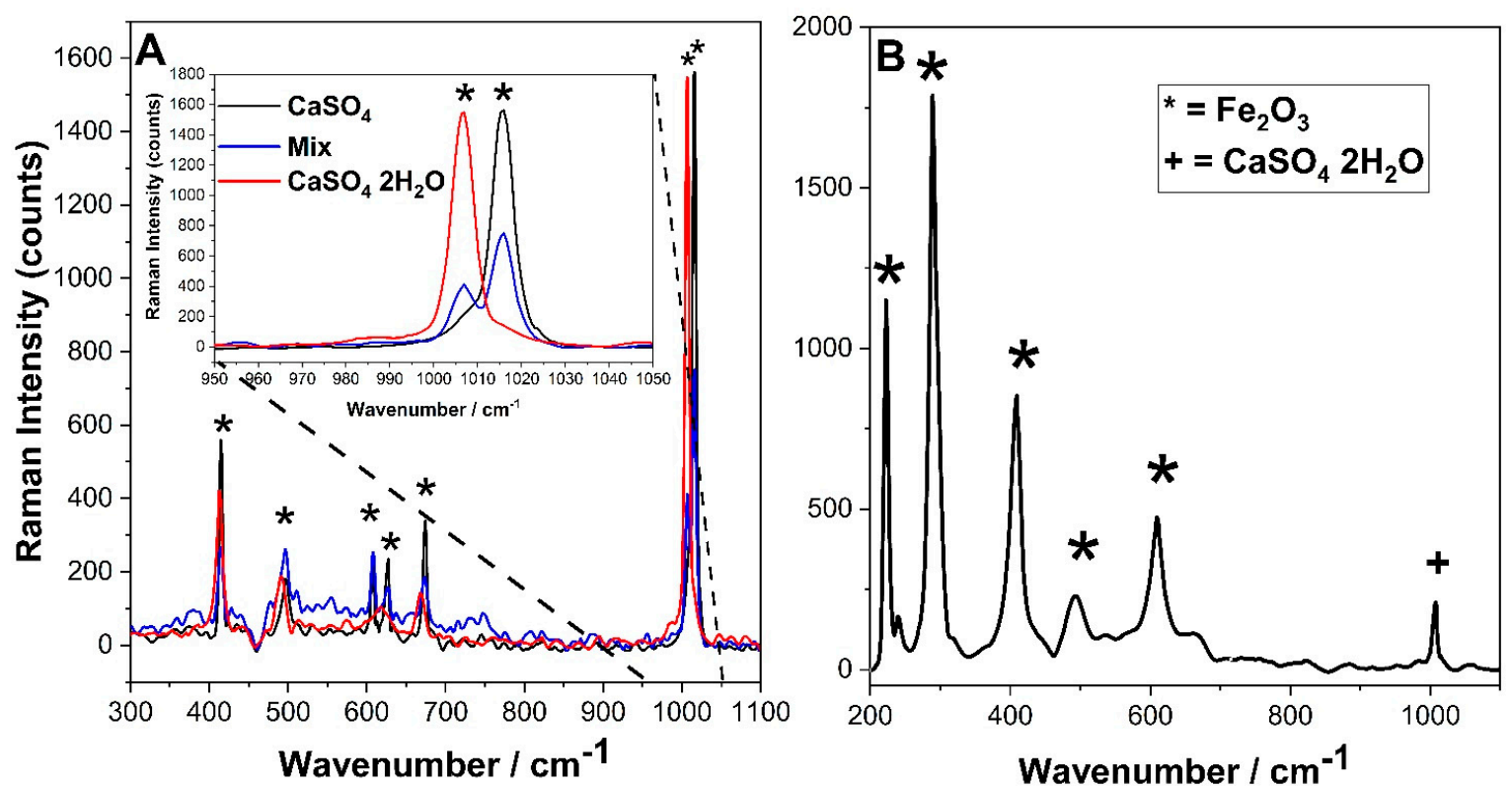

Figure 10. Raman spectra acquired on the ground of the painting cross-section: (A) Raman spectra acquired on white grains (B) Raman spectrum acquired on red grains.

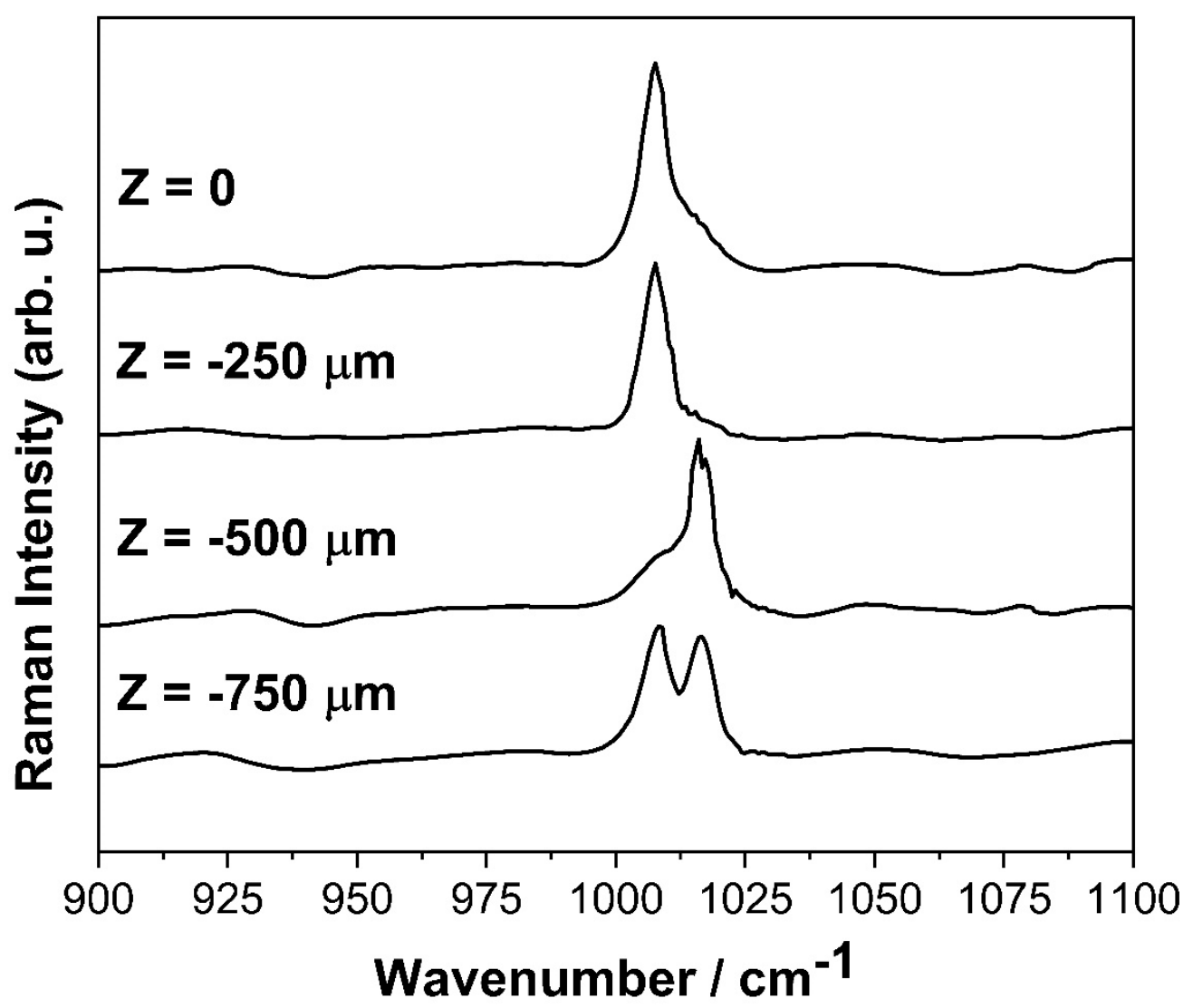

Figure 11. Raman spectra acquired at different depth $(Z)$ on the ground of the painting cross-section. $Z$ $=0$ corresponds to the surface underneath the Ag layer.

Raman vibrational modes assignments of $\mathrm{CaSO}_{4}, \mathrm{Ag}_{2} \mathrm{~S}$, and $\mathrm{Ag}_{2} \mathrm{O}$ compounds are reported in Table $1[28,31]$. 
Table 1. Raman vibrational modes assignments of $\mathrm{CaSO}_{4}, \mathrm{Ag}_{2} \mathrm{~S}$, and $\mathrm{Ag}_{2} \mathrm{O}$ compounds.

\begin{tabular}{|c|c|c|c|}
\hline Compounds & Raman Frequency $\left(\mathrm{cm}^{-1}\right)$ & Assignments & Comments \\
\hline \multirow{7}{*}{$\mathrm{CaSO}_{4}\left(2 \mathrm{H}_{2} \mathrm{O}\right)$} & 415 & $v_{2}\left(\mathrm{SO}_{4}\right)$ & Dihydrate \\
\hline & 496 & $v_{2}\left(\mathrm{SO}_{4}\right)$ & Dihydrate \\
\hline & 607 & $v_{4}\left(\mathrm{SO}_{4}\right)$ & Anhydrate \\
\hline & 627 & $v_{2}\left(\mathrm{SO}_{4}\right)$ & Anhydrate \\
\hline & 675 & $v_{2}\left(\mathrm{SO}_{4}\right)$ & Dihydrate \\
\hline & 1007 & $v_{1}\left(\mathrm{SO}_{4}\right)$ & Dih./Anh. \\
\hline & 1015 & $v_{3}\left(\mathrm{SO}_{4}\right)$ & Anhydrate \\
\hline \multirow{3}{*}{$\mathrm{Ag}_{2} \mathrm{~S}$} & 158 & Ag lattice & \\
\hline & 198 & $v(\mathrm{Ag}-\mathrm{S})$ & \\
\hline & 281 & $v(\mathrm{Ag}-\mathrm{S})$ & \\
\hline \multirow{4}{*}{$\mathrm{Ag}_{2} \mathrm{O}$} & 236 & \multirow{4}{*}{$\begin{array}{l}v(\mathrm{Ag}-\mathrm{O}) \\
\delta(\mathrm{Ag}-\mathrm{O})\end{array}$} & \\
\hline & 425 & & \\
\hline & 491 & & \\
\hline & 563 & & \\
\hline
\end{tabular}

\section{Discussion}

According to a top-down/bottom-up procedure, the multianalytical approach followed in this work provided valuable information for the discussion of all the gathered results, opening new readings on the artistic execution technique of this rare artwork. Over the Ag leaf, two different organic layers were found. An oil-based topcoat, probably blended with a natural resin, might have been used as the "mecca" layer to make the silver ground brighter and like gold, thus recalling gilding techniques and procedures mentioned in many historical treaties [10]. However, although analytically challenging, no signals relative to natural dyes (curcuma, saffron, and aloe) added to imitate gold were found neither using DRIFT nor micro-ATR-FTIR spectroscopies. Beneath this layer, a thin organic layer applied originally over the silver leaf to protect it from tarnishing was found. The latter was composed of egg yolk with wax, in part or completely transformed over time into a calcium oxalate film. These outcomes were further strengthened by UVIVF microfluorimetry. In contrast to the topcoat, the broad, low-intensity and remarkably red-shifted fluorescence emission of the thin layer over the Ag leaf reflects very well the composition of an aged and altered organic layer. More importantly, the latter figured out also a "wavy" profile when observed in the transverse section under UVIVF microscopy, indicating either that it was still fresh when the uppermost layer was applied or that the latter was later added causing softening and partial dissolution of the underlying layer. These two assumptions shed new light on the execution technique of this painting, opening also new possible ways of interpretation. Technically, it has more sense that the uppermost layer was later added as past conservation treatment rather than applied when the underlying layer was still fresh. The lack of the top oil coat in the sampled fragment on the frame went in this direction. Contrarily, what would be the function of this thick oil coat later added? If intended to impart a golden hue to the silver leaf as sort of a "mecca" layer it should have been applied over the metal leaf. In this scenario, the second hypothesis becomes more reliable as well as the function of the old thin layer covering the Ag leaf. The latter could have been thought either as a final application for protecting the leaf and for increasing or reducing its shine, thus for an aesthetic reason. It is worth reporting that the use of egg yolk and wax could not be casual and reflects to some extent the cold-encaustic technique, notoriously called "Punic wax". In this technique, the wax before to be added to protein compounds (casein, egg, gum, and glue) was made water-soluble following an alkali treatment with lime. The addition of wax leads to improve adhesion, spreading, and transparency of the medium as well as the resistance to moisture [32]. In this painting, 
a similar binder was likely used to protect and make more shine the silver leaf. Further confirmations supporting what was stated until now may be found in the method used to apply the silver leaf. In this regard, UV images and SEM analysis showed that silver leaf was applied directly over a white ground, as no evidence of a mordant layer was seen. The silver leaf was very thin, on the order of $100 \mathrm{~nm}$. As said, it was attached directly to the preparation layer without using a colored bole. The Ag leaf followed precisely the shape of the preparation layer underneath with amazing accuracy suggesting that burnishing occurred afterward. The preparation layer constituted by calcium sulphate and a protein binder appeared to have different compositions depending on the depth from the Ag layer. In this respect, the use of anhydrate and calcium sulphate dihydrate had two different purposes: the first, called "gesso grosso" (coarse gypsum) with a composition of 100\% anhydrite (either 75:25 or 50:50 anydrite:dihydrate) was usually used for the preparation of the bulk of the ground; the latter, called "gesso sottile" (thin gypsum) with a composition of 100\% dihydrite (or 75:25 dihydrate:anhydrate) was used closer to the metal layers as a kind of preparation layer [33]. In line with the preparatory technique of that time, a different distribution of calcium sulphate dihydrate and anhydrite mineral phases was observed within the distance from the surface. Anhydrate (gesso grosso) was found mainly in the bulk of the ground, whereas calcium sulphate dihydrate (gesso sottile) was found closer to the metal layers as a kind of white bole layer [34-36]. This result further corroborates the execution of the water gilding technique, where the use of a white ground bole served the purpose to burnish the applied Ag leaf.

Finally, it can be stated that after silvering, the surface could have been burnished for obtaining brightness and whiteness ("argento biancheggiato") [32]. Thereby, in the absence of a warm-colored bole layer, it would seem, that the artist's final intention was not to achieve a gold-like appearance. This final interpretation on the gilding technique further supports that the thin layer spread out over the silver leaf was conceived as a finishing treatment.

\section{Conclusions}

The analysis carried out on the painting depicting the "Virgin with the Child and two angels" by a Tuscan anonymous allowed the shedding of light on a few issues about the pictorial execution technique of the XIII century. Particularly important is the rare use of the silver leaf, unreported so far in the scientific literature. The use of a multilayered white ground, the application of the silver leaf applied without mordanting, the consequent burnishing of the leaf, and the wax binder as the finished layer led to the conclusion that this artwork was not conceived to be a surrogate of gilding ("argento deaurato"). More plausibly, it is rather an original and rare example of water silvering, where silver leaves were intentionally applied to give a silvered look ("argento biancheggiato"). This finding could help to improve technical knowledge of the silver leaf gilding of the 13th century as well as can be seen as a sort of added value to the originality of this artwork.

Supplementary Materials: The following are available online at http:/www.mdpi.com/2076-3417/10/7/2404/s1, Figure S1: IR bands vibrational modes of the spectra acquired on different sampled paint fragments (see Figure 8).

Author Contributions: Conceptualization, I.O. and D.C.; methodology, I.O. and D.C.; validation, I.O., D.C. and L.G.; formal analysis, I.O., D.C., M.B., L.C. and B.S.; investigation, I.O., D.C. and L.G.; data curation, I.O., D.C., M.B. and B.S.; writing-original draft preparation, I.O. and D.C.; writing-review and editing, I.O., D.C., M.B., P.M., L.G. and B.S.; supervision I.O.; project administration, L.G.; funding acquisition, A.L. and S.S. All authors have read and agreed to the published version of the manuscript.

Funding: The authors also thank for funding: Fondazione CR Firenze for the grant Number n. 2013.0878 and Regione Toscana POR FESR 2014-2020 for the project FELIX (Fotonica ed Elettronica Integrate per l'Industria), Grant Number 6455.

Conflicts of Interest: The authors declare no conflict of interest. 


\section{References}

1. Popova, O.; Smirnova, E.; Cortesi, P. Icone: Guida Completa Al Riconoscimento Delle Icone Dal VI Secolo A Oggi, Guide Cultura; Mondadori Electa: Milano, Italy, 2003.

2. Christoph, M. Dorature E Policromie Delle Parti Architettoniche Nelle Tavole D'altare Toscane Tra Trecento E Quattrocento; Nardini Editore: Firenze, Italy, 1996.

3. Mafodda, B. Oro, Argento E Oro Di Metà Nell'adorazione Dei Magi Di Gentile Da Fabriano. Master's Thesis, Università degli Studi di Firenze, Firenze, Italy, 2020.

4. $\quad$ Middeldorf, U.; Di Bicci, N. Neri di Bicci. Le Ricordanze (10 Marzo 1453-24 Aprile 1475), A Cura Di Bruno Santi; Edizioni Marlin: Pisa, Italy, 1976.

5. Lalli, C.F. Innocenti La doratura nelle tecniche artistiche. OPD Restauro 2016, 28, 340-349.

6. Osticioli, I.; Capozzoli, L.; Salvadori, B.; Banchelli, M.; Lavacchi, A.; Matteini, P.; Siano, S.; Gallo, L. The “oro di metà" Gilding in the Fifteenth-Century: A Multi-Analytical Investigation. Heritage 2019, 2, 1166-1175. [CrossRef]

7. Osticioli, I.; Lavacchi, A.; Capozzoli, L.; Berretti, E.; Gallo, L.; Berberich, C.; Agresti, J.; Siano, S. Novel insights on the study of a fifteenth-century oro di metà/Zwischgold gilding by means of ion and electron microscopy: characterization of the stratigraphy avoiding cross-sections preparation. J. Cult. Heritage 2020. [CrossRef]

8. Wu, Q.; Lombardo, T.; Hubert, V.; Hildbrand, E.; Wyer, P.; Nolting, F.; Ganz, D. New insights into Zwischgold application from a multi-analytical survey of late medieval polychrome sculptures at the Swiss National Museum. Microchem. J. 2020. [CrossRef]

9. Sbarbaro, M. Circolazione Di Idee E Di Esperienze Economiche Nell'italia Del Duecento. La Coniazione Del Ducato Veneziano: Scelta Politica O Economica? In Cultura Cittadina E Documentazione. Formazione E Circolazione Di Modelli; CLUEB: Bologna, Italy, 2009.

10. Sandu, I.C.A.; Afonso, L.U.; Murta, E.; de Sa, M.H. Gildings techniques in religious art between east and west, 14th-18th centuries. Int. J. Conserv. Sci. 2010, 1, 47-62.

11. Nef, J.U. Silver Production in Central Europe, 1450-1618. J. Politi- Econ. 1941, 49, 575-591. [CrossRef]

12. Byrne, J.P.; Stahl, A.M. Zecca: The Mint of Venice in the Middle Ages; The Johns Hopkins University Press: London, UK, 2000.

13. Thoury, M.; Elias, M.; Frigerio, J.M.; Barthou, C. Nondestructive Varnish Identification by Ultraviolet Fluorescence Spectroscopy. Appl. Spectrosc. 2007, 61, 1275-1282. [CrossRef]

14. Manfredi, M.; Barberis, E.; Rava, A.; Robotti, E.; Gosetti, F.; Marengo, E. Portable diffuse reflectance infrared Fourier transform (DRIFT) technique for the non-invasive identification of canvas ground: IR spectra reference collection. Anal. Methods 2015, 7, 2313-2322. [CrossRef]

15. Beltrán, V.; Salvadó, N.; Butí, S.; Cinque, G. Micro infrared spectroscopy discrimination capability of compounds in complex matrices of thin layers in real sample coatings from artworks. Microchem. J. 2015, 118, 115-123. [CrossRef]

16. Martín-Ramos, P.; Fernández-Coppel, I.A.; Ruíz-Potosme, N.M.; Martín-Gil, J. Potential of ATR-FTIR Spectroscopy for the Classification of Natural Resins. Boil. Eng. Med. Sci. Rep. 2018, 4, 03-06. [CrossRef]

17. Azémard, C.; Vieillescazes, C.; Menager, M. Effect of photodegradation on the identification of natural varnishes by FT-IR spectroscopy. Microchem. J. 2014, 112, 137-149. [CrossRef]

18. Ciofini, D.; Striova, J.; Camaiti, M.; Siano, S. Photo-oxidative kinetics of solvent and oil-based terpenoid varnishes. Polym. Degrad. Stab. 2016, 123, 47-61. [CrossRef]

19. Meilunas, R.J.; Bentsen, J.G.; Steinberg, A. Analysis of Aged Paint Binders by FTIR Spectroscopy. Stud. Conserv. 1990, 35, 33-51.

20. Invernizzi, C.; Rovetta, T.; Licchelli, M.; Malagodi, M. Mid and Near-Infrared Reflection Spectral Database of Natural Organic Materials in the Cultural Heritage Field. Int. J. Anal. Chem. 2018, 2018, 1-16. [CrossRef]

21. Mazzeo, R.; Prati, S.; Quaranta, M.; Joseph, E.; Kendix, E.; Galeotti, M. Attenuated total reflection micro FTIR characterisation of pigment-binder interaction in reconstructed paint films. Anal. Bioanal. Chem. 2008, 392, 65-76. [CrossRef]

22. La Russa, M.F.; Ruffolo, S.A.; Barone, G.; Crisci, G.M.; Mazzoleni, P.; Pezzino, A. The Use of FTIR and Micro-FTIR Spectroscopy: An Example of Application to Cultural Heritage. Int. J. Spectrosc. 2009, 2009, 1-5. [CrossRef] 
23. Monico, L.; Rosi, F.; Miliani, C.; Daveri, A.; Brunetti, B.G. Non-invasive identification of metal-oxalate complexes on polychrome artwork surfaces by reflection mid-infrared spectroscopy. Spectrochim. Acta Part A: Mol. Biomol. Spectrosc. 2013, 116, 270-280. [CrossRef]

24. Miliani, C.; Rosi, F.; Daveri, A.; Brunetti, B.G. Reflection infrared spectroscopy for the non-invasive in situ study of artists' pigments. Appl. Phys. A 2011, 106, 295-307. [CrossRef]

25. Dias, T.; Murta, E.; Dias, C.B.; Serrão, V. All that glitters is not gold: silver leaf gilding, another means to an end. Conserv. Patrim. 2015, 22, 29-40. [CrossRef]

26. Maclennan, D.; Llewellyn, L.; Delaney, J.K.; Dooley, K.A.; Patterson, C.S.; Szafran, Y.; Trentelman, K. Visualizing and measuring gold leaf in fourteenth-and fifteenth-century Italian gold ground paintings using scanning macro X-ray fluorescence spectroscopy: A new tool for advancing art historical research. Herit. Sci. 2019, 7, 25. [CrossRef]

27. Atrei, A.; Scala, A.; Giamello, M.; Uva, M.; Pulselli, R.M.; Marchettini, N. Chemical Composition and Micro Morphology of Golden Laminae in the Wall Painting "La Maestà" by Simone Martini: A Study by Optical Microscopy, XRD, FESEM-EDS and ToF-SIMS. Appl. Sci. 2019, 9, 3452. [CrossRef]

28. Martina, I.; Wiesinger, R.; Jembrih-Simbürger, D.; Schreiner, M. Micro-Raman Characterisation Of Silver Corrosion Products: Instrumental Set Up And Reference Database. E-Preserv. Sci. 2012, 9, 1-8.

29. Martina, I.; Wiesinger, R.; Schreiner, M. Micro-Raman investigations of early stage silver corrosion products occurring in sulfur containing atmospheres. J. Raman Spectrosc. 2013, 44, 770-775. [CrossRef]

30. Gettens, R.J.; Mrose, M.E. Calcium sulphate minerals in the grounds of italian paintings. Stud. Conserv. 1954, 1, 174-189.

31. Kloprogge, T.; Frost, R.L. Raman microscopy at $77 \mathrm{~K}$ of natural gypsum CaSO4-2H2O. J. Mater. Sci. Lett. 2000, 19, 229-231. [CrossRef]

32. Cuní, J.; Cuní, P.; Eisen, B.; Savizky, R.; Bové, J. Characterization of the binding medium used in Roman encaustic paintings on wall and wood. Anal. Methods 2012, 4, 659-669. [CrossRef]

33. Federspiel, B. Questions about Medieval Gesso Grounds, in Historical Painting Techniques, Materials, and Studio Practice Preprints of a Symposium, University of Leiden, the Netherlands, 26-29 June 1995; Wallert, A., Hermens, E., Peek, M., Eds.; The Getty conservation Institute: Los Angeles, CA, USA, 1995.

34. Cardoso, I.P.; Pye, E. Preparing the foundation for stable gilding: Baroque craftsmen's empirical understanding of gesso gilding grounds. J. Archaeol. Sci. 2017, 79, 96-106. [CrossRef]

35. Cardoso, I.P.; Pye, E. Gessoes in Portuguese Baroque Gilding Grounds: Part 2: Analytical Study of Historical Samples and Archaeological Reconstructions. Stud. Conserv. 2017, 63, 72-96. [CrossRef]

36. Cardoso, I.P.; Pye, E. Gessoesin Portuguese Baroque gilding grounds, part 1: A study of historical documentary sources. Stud. Conserv. 2016, 62, 185-209. [CrossRef]

(C) 2020 by the authors. Licensee MDPI, Basel, Switzerland. This article is an open access article distributed under the terms and conditions of the Creative Commons Attribution (CC BY) license (http://creativecommons.org/licenses/by/4.0/). 